\section{Экспериментальное определение объема лесосечных отходов}

\author{
О. Н. Галактионов ${ }^{1}$ \\ Петрозаводский государственный университет
}

\section{АННОТАЦИЯ}

Статья посвящена исследованию структуры лесосечных отходов на лесосеке и ее изменению в условиях смены типов технологических процессов в лесозаготовительном комплексе. Также приводятся результаты исследования объема лесосечных отходов на лесосеках Пудожского района.

Ключевые слова: технологический прочесс, лесосечные отходы, объем, измерения.

\section{SUMMARY}

The article is devoted to research of logging waste structure, on cutting area and its change in conditions of change of technological processes types in the forest complex. Results of research of logging waste volumes on the cutting area of Pudog region are presented.

Keywords: technology process, logging waste, volume, measurements.

На многих лесозаготовительных предприятиях происходит процесс замены технологии хлыстовой заготовки сортиментной. Этот процесс совпадает с изменением требований лесопереработчиков к поставляемому сырью.

В связи с этим происходит изменение сортиментной структуры, как качественно, так и количественно, круглых лесоматериалов, заготавливаемых на лесопромышленных предприятиях, изменился и объем лесосечных отходов, оставляемых на лесосеке, в сторону увеличения.

Указанные лесосечные отходы могут служить топливом в процессах получения тепла и электроэнергии, а при разработке соответствующих агрегатов и источником сырья для получения продукции деревообработки.

Для определения экономической целесообразности применения тех или иных технологических процессов необходимо исследовать объемы образующихся лесосечных отходов и их размерные параметры.

Основой для настоящего исследования послужили материалы, собранные в процессе проведения работ по переобучению рабочих (вальщиков) ОАО «Пудожпромлес».

\footnotetext{
${ }^{1}$ Автор - дочент кафедры технологии и оборудования лесного комплекса
}

(c) О. Н. Галактионов, 2003
Исследование проводилось в Онежском лесничестве Пудожского лесхоза, квартал 131, время проведения исследования - октябрь 2002 года.

Всего было проведено 142 измерения. Измерялись диаметр в нижнем отрубе, длина вершины, число стволов в пробе.

Характеристики лесного фонда: площадь выдела 22 га, запас - $150 \mathrm{~m}^{3} /$ га, общий - $3400 \mathrm{~m}^{3}$, состав: ель $90 \%$, остальные - до $10 \%$, средний диаметр - 18 см, средняя высота - 21 м. Способ рубки - сплошная, технология - сортиментная, вальщики проводили валку, обрубку сучьев, раскряжевку, окучивание сортиментов, форвардеры транспортировали сортименты к погрузочной площадке. Ширина пасечных волоков 5 м, посередине лесосеки проходил лесовозный ус, магистральный волок отсутствовал, угол между волоком и усом $80^{\circ}$, средняя длина волоков 85 м.

На момент проведения измерений на лесосеке были прорублены волока на всю ширину лесосеки и отделены деловые сортименты - пиловочник 6 и 5 м, баланс 4,5 и 5,2 м. В состав лесосечных отходов включались: вершины диаметром 12 см и тонкомер.

Результаты измерений и некоторые статистические характеристики представлены в таблице 1, гистограмма по опытным данным - на рис. 1.

Исследования проводились на половине лесосеки, в части, полностью пройденной волоками. Методика проведения измерений заключалась в следующем: через лесосеку вдоль ее длины намечался путь (рис. 2), на котором предполагалось провести измерения, по мере пересечения волоков с расположенными на них лесосечными отходами, проводились измерения их диаметров и длин, диаметры фиксировались, начиная с диаметра $3 \mathrm{~cm}$, измерялась длина с градацией 0,5 м, проводился подсчет вершин, представляющих интерес для переработки.

По величине стандартного отклонения и эксцесса можно говорить об отклонении от нормального закона распределения, а по гистограммам видно, что указанные распределения могут быть аппроксимированы логнормальным распределением.
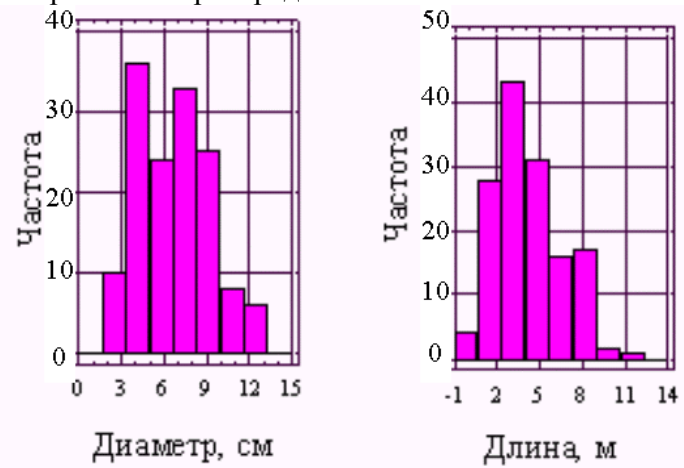

Рис. 1. Гистограммы опытных данных 


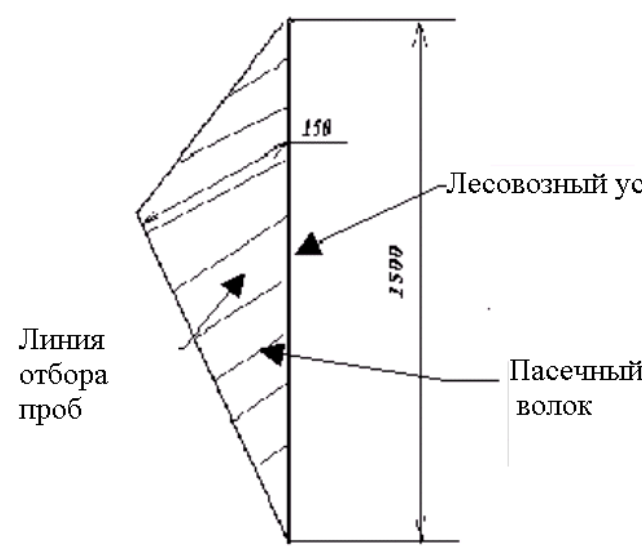

Рис. 2. Схема лесосеки и расположения линии отбора проб

Таблица 1

Характеристики выборок

\begin{tabular}{|c|c|c|c|}
\hline Характеристика & $\begin{array}{c}\text { Диа- } \\
\text { метр }\end{array}$ & $\begin{array}{c}\text { Дли } \\
\text { на }\end{array}$ & $\begin{array}{c}\text { Число } \\
\text { вершин } \\
\text { в пробе }\end{array}$ \\
\hline Число измерений & 142 & 142 & 34 \\
\hline Среднее, см & 6,9 & 4,2 & 4,5 \\
\hline Дисперсия & 6,3 & 5,5 & 3,6 \\
\hline $\begin{array}{c}\text { Стандартное откло- } \\
\text { нение }\end{array}$ & 2,5 & 2,3 & 1,9 \\
\hline Стандартная ошибка & 0,2 & 0,2 & 0,3 \\
\hline $\begin{array}{c}\text { Минимальное зна- } \\
\text { чение, см }\end{array}$ & 3,0 & 0,2 & 2,0 \\
\hline $\begin{array}{c}\text { Максимальное зна- } \\
\text { чение, см }\end{array}$ & 13,0 & 11,1 & 8,0 \\
\hline $\begin{array}{c}\text { Стандартный экс- } \\
\text { цесс }\end{array}$ & 1,4 & 2,6 & 0,7 \\
\hline $\begin{array}{c}\text { Стандартная асим- } \\
\text { метрия }\end{array}$ & $-2,0$ & $-1,1$ & $-1,2$ \\
\hline $\begin{array}{c}\text { Коэффициент вари- } \\
\text { ации, \% }\end{array}$ & 36,1 & 55,2 & 42,4 \\
\hline
\end{tabular}

В дальнейшем проводилась обработка измерений методом линейных пересечений с использованием основной формулы метода для определения средних характеристик объектов на площади:

$$
\bar{X}=\frac{\pi S_{W}}{G} \bar{x} \sum_{O}^{n} \frac{1}{l_{i}},
$$

а также формулы для определения суммарных характеристик выборки:

$$
\sum_{0}^{\mathrm{N}} \mathrm{X}_{\mathrm{i}}=\frac{\pi S_{W}}{G} \sum_{0}^{\mathrm{n}} \frac{\mathrm{x}_{\mathrm{i}}}{l_{i}}
$$

Минимальная длина пробной линии определялась по формуле:

$$
L=\sqrt{\frac{\sum^{k} x_{i}{ }^{2}}{\frac{3 \sigma}{h_{i}}-\sum^{k} \bar{x}_{L i}+2 \bar{x}_{L} \sum^{k} x_{L i}}}
$$

Форма и площадь области должны подчиняться условию:

$$
\frac{G}{S_{W}} \geq \frac{0,95 \pi}{l_{c p}}
$$

В приведенных формулах $\mathrm{x}_{\mathrm{i}}$ - величина измеряемого признака (диаметр), м; $1_{\mathrm{i}}$ - длина измеряемого объекта, м; $\bar{x}$ - средняя величина признака, м; L - длина линии отбора проб, м; $\mathrm{G}$ - характеристика формы и площади; $1_{c p}-$ средняя длина объекта, м; $\mathrm{S}_{\mathrm{w}}$ - площадь исследуемой области, м².

Все необходимые условия для проведения измерений были выполнены.

После обработки данных измерений были получены следующие результаты:

средний диаметр лесосечных отходов $-6,5$ см;

средняя длина лесосечных отходов - 8,4 м;

объем лесосечных отходов после пробивки волоков составил $60 \mathrm{~m}^{3}$, что позволяет оценить объем лесосечных отходов для лесосеки в целом $-660 \mathrm{~m}^{3}$.

Таким образом, в современных условиях структура и объем лесосечных отходов значительно изменились.

Проведенное исследование может служить основой для дальнейшего более подробного исследования с целью определения перспективных путей использования указанных лесосечных отходов. 
